\title{
Endemic Land Snail Fauna (Mollusca) on a Remote Peninsula in the Ogasawara Archipelago, Northwestern Pacific ${ }^{1}$
}

\author{
Satoshi Chiba ${ }^{2,3}$, Angus Davison, ${ }^{4}$ and Hideaki Mori ${ }^{3}$
}

\begin{abstract}
Historically, the Ogasawara Archipelago harbored more than 90 native land snail species, $90 \%$ of which were endemic. Unfortunately, about $40 \%$ of the species have already gone extinct across the entire archipelago. On Hahajima, the second-largest island and the one on which the greatest number of species was recorded, more than $50 \%$ of species are thought to have been lost. We report here the results of a recent survey of the snails of a remote peninsula, Higashizaki, on the eastern coast of Hahajima. Although the peninsula is small $\left(\sim 0.3 \mathrm{~km}^{2}\right)$ and only part is covered by forest $\left(<0.1 \mathrm{~km}^{2}\right)$, we found 12 land snail species, all of which are endemic to Ogasawara. Among these species, five had been thought to already be extinct on Hahajima, including Ogasawarana yoshiwarana and Hirasea acutissima. Of the former, there has been no record since its original description in 1902. Except for the much larger island of Anijima and the main part of Hahajima, no single region on the Ogasawara Archipelago maintains as great a number of native land snail species. It is probable that the land snail fauna of the Higashizaki Peninsula is exceptionally well preserved because of a lack of anthropogenic disturbance and introduced species. In some circumstances, even an extremely small area can be an important and effective refuge for threatened land snail faunas.
\end{abstract}

The native Land snail fauna of the Pacific islands is one of the most seriously endangered faunas in the world (e.g., Murray et al. 1988, Cowie 2001, 2002, Cowie and Robinson 2003, Lydeard et al. 2004). Approximately $50 \%$ of the native land snail species in the Pacific region are already threatened as a result of the impact of habitat destruction and introduced predators (Lydeard et al. 2004). The land snail fauna of the Ogasawara Archipelago in the northwestern Pacific is

${ }^{1}$ This research was supported by the Global Environment Research Fund (F-051). Manuscript accepted 7 June 2006. .jp).

${ }^{2}$ Corresponding author (schiba@biology.tohoku.ac

${ }^{3}$ Graduate School of the Life Sciences, Tohoku University, Aobayama, Sendai, 980-8578, Japan.

${ }^{4}$ Institute of Genetics, School of Biology, QMC, University of Nottingham, Nottingham, NG7 2UH, United Kingdom.

Pacific Science (2007), vol. 61, no. 2:257-265

(C) 2007 by University of Hawai'i Press

All rights reserved one such example: of 95 recorded species, more than $90 \%$ are endemic (Kuroda 1930, Habe 1969, Minato 1979, Chiba 1989, Tomiyama and Kurozumi 1991). Unfortunately, about $40 \%$ of the identified species from Ogasawara may have already gone extinct (Kurozumi 1988, Tomiyama and Kurozumi 1991) because of habitat degradation (e.g., cultivation, grazing by goats) and destruction of native forest, as well as predation by introduced species (e.g., flatworms, the predatory snail Euglandina rosea, rats) (Shimizu et al. 1991, Okochi et al. 2004). Even on Anijima, the island where the native habitat is most intact, and where all of the native snail species still survive, continuing grazing by goats and predation by rats and flatworms may soon lead to extinction of the snail fauna.

Hahajima Island, the second-largest island $\left(20 \mathrm{~km}^{2}\right)$ and the most variable in habitat, has the greatest number of recorded snail species (54) among the islands of Ogasawara, but it is believed that around half have already gone extinct (Tomiyama and Kurozumi 1991). We recently surveyed the land snail fauna of a remote peninsula, Higashizaki, in the eastern 
part of Hahajima (Figure 1). This peninsula consists of a plateau about $100 \mathrm{~m}$ above sea level that is surrounded by vertical cliffs around $50-80 \mathrm{~m}$ in height (the highest point is $114 \mathrm{~m}$ above sea level). The total area is about $0.3 \mathrm{~km}^{2}$, of which less than $0.1 \mathrm{~km}^{2}$ is forested. The only access point from Hahajima is by first climbing the highest mountain on Hahajima (Chibusayama: $400 \mathrm{~m}$ above sea level), then descending to a narrow ridge (parts completely lack vegetation because of erosion) that crosses to the peninsula (Figures $1,2)$. The land snail fauna of this peninsula had never before been surveyed. Before visiting, we were hopeful that the habitat might be in its original condition and that few introduced species would be found.

\section{MATERIALS AND METHODS}

The survey of the Higashizaki Peninsula was conducted in November 2003 and October 2005. First, the condition of the habitat was investigated, and the most likely locations for snails noted. Following some preliminary surveys of the snail fauna, four localities were selected for more detailed examination (Figure 1). We searched on the forest floor and also in the trees (sites 1, 3, 4). Bushes and grassland around the forest were also examined (site 2). First, we searched within a 10 by 10 $\mathrm{m}$ quadrat to locate arboreal species and large species such as those in the genus Mandarina (20-30 $\mathrm{mm}$ size) in the leaf litter. After recording them, we searched more thoroughly for small snail species $(<10 \mathrm{~mm})$ by placing 0.5 by $0.5 \mathrm{~m}$ quadrats at random within the 10 by $10 \mathrm{~m}$ quadrate. Leaves were removed carefully and all snails found were recorded. In addition, the litter was taken from a 0.2 by $0.2 \mathrm{~m}$ area from each 0.5 by $0.5 \mathrm{~m}$ quadrat to check for microsnails and parts of dead shells. See Table 1 for the number of 0.5 by $0.5 \mathrm{~m}$ quadrats per site.

Species were identified at the study sites, but some samples were also brought to the laboratory. These vouchers representing all species were deposited in the University Museum of the Tohoku University (Tumc24801-24804). Based on the occurrence of the snail species in each study site, species richness and population density of each species (numbers per $1-\mathrm{m}^{2}$ area) were estimated at each site and across all sites. The frequencies of endemic species, indigenous species, and alien species in the land snail fauna of Higashizaki were compared with those of other areas of Hahajima and the other islands of Ogasawara.

\section{RESULTS}

The forest in the central part of the plateau of the Higashizaki Peninsula is mainly composed of palm trees (Livistona chinensis), pandanus trees (Pandanus boninensis), and shrubby broad-leaved trees (e.g., Macilus kobu). No alien predators of snails such as predatory flatworms, rats, and the predatory snail $\mathrm{Eu}$ glandina rosea were found on the peninsula.

Land snails were remarkably abundant on the forest floor, especially under the leaf litter. The rough surveys revealed no species not found in detailed studies of the four sites. In total, 12 species were found (Table 1), all of which are endemic to Ogasawara. These included species that have already gone extinct in the main part of Hahajima (Ogasawara yoshiwarana, Ogasawara arata, Ptychalaea dedecora, Hirasea acutissima, and Lamprocystis babajimana) and have not been recorded there since the 1940s. Of special interest, Ogasawarana yoshiwarana and Hirasea acutissima (Figure 3) were previously believed to be entirely extinct because they are endemic to Hahajima. Ogasawarana yoshiwarana is listed as extinct in the IUCN Red List (2004) and Hirasea acutissima as extinct in the Red List of Japan (Ministry of Environment Japan 2000). Ogasawarana yoshiwarana has not been recorded since it was originally discovered and formally described by Pilsbry (1902).

The other seven species that were found still survive in the main part of Hahajima. However, Mandarina habajimana on Higashizaki appears to be ecologically and morphologically distinct from those in other areas of Hahajima. In the main part of Hahajima this species lives on trees and has a thin, small shell with an open umbilicus, whereas on Higashizaki it lives on the ground and has a 

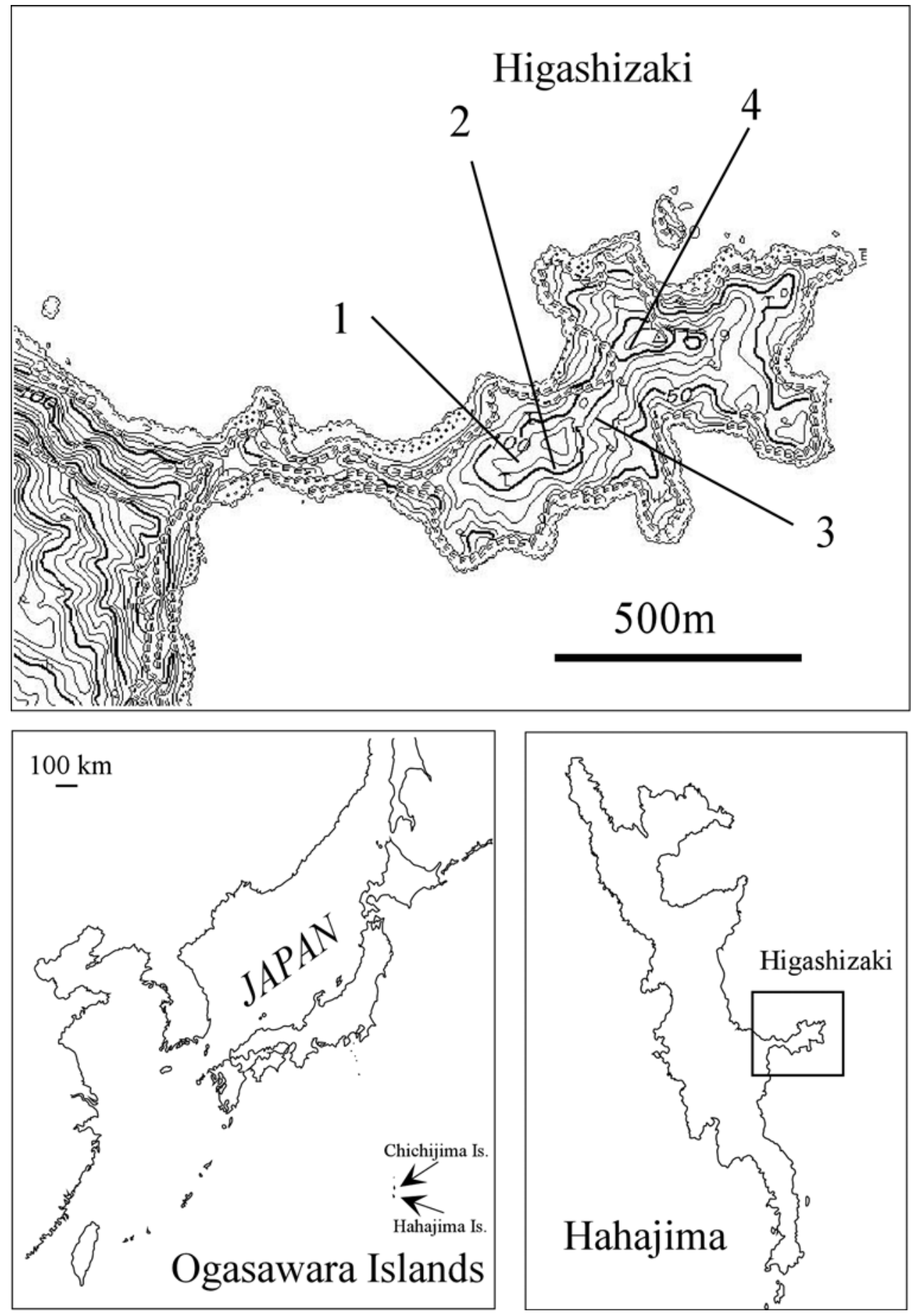

Figure 1. A map of the Higashizaki Peninsula on Hahajima Island in the Ogasawara Islands, showing the locations of the study sites. 


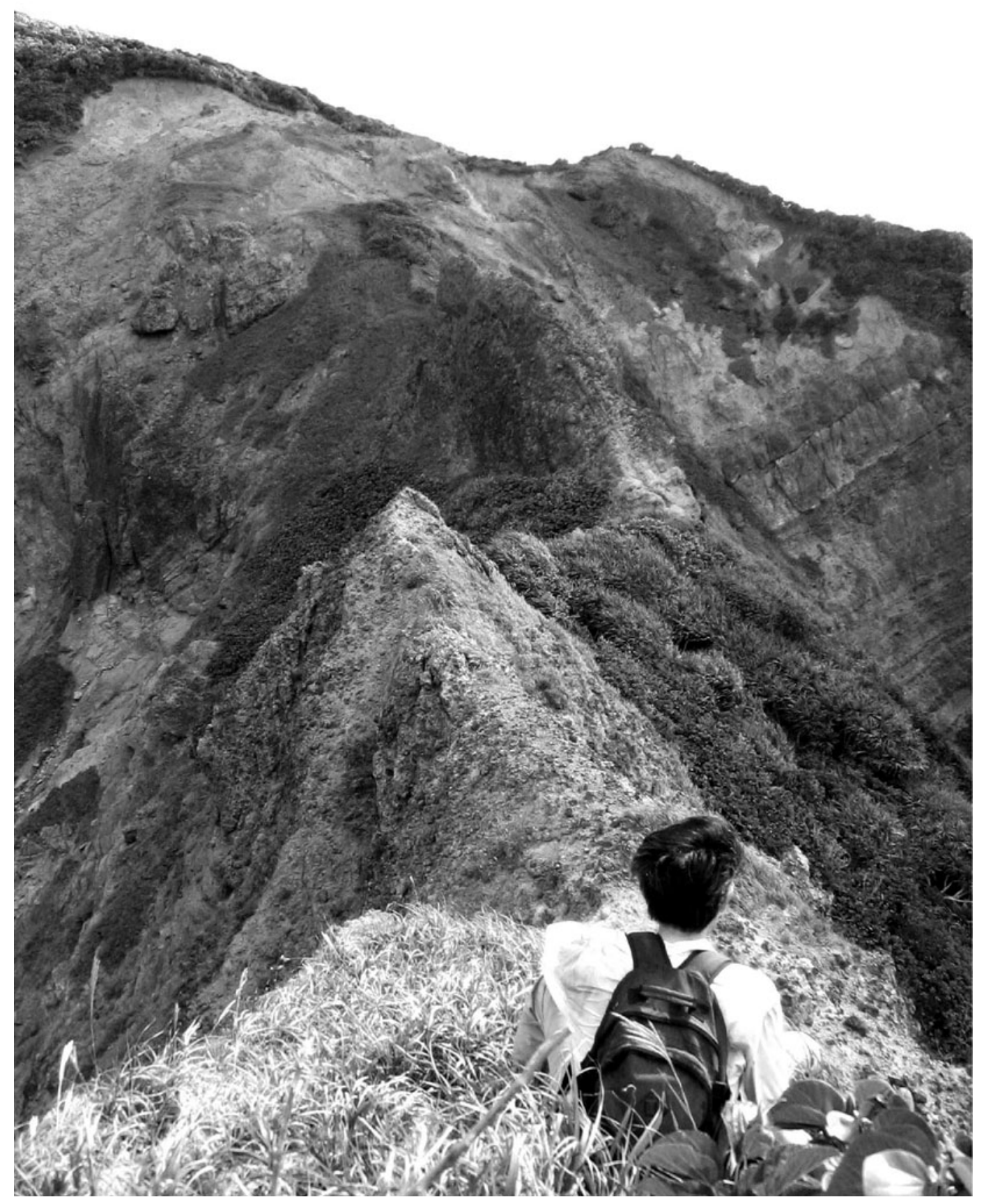

Figure 2. Photograph of the ridge that connects the Higashizaki Peninsula to Hahajima. 
TABLE 1

Land Snail Species Found on the Higashizaki Peninsula

\begin{tabular}{|c|c|c|c|c|}
\hline \multirow[b]{3}{*}{ Species } & \multicolumn{4}{|c|}{ Sites } \\
\hline & 1 & 2 & 3 & 4 \\
\hline & \multicolumn{4}{|c|}{ Numbers/Density (no. per $\mathrm{m}^{2}$ ) } \\
\hline Ogasawarana yoshiwarana Pilsbry & $103 / 103.0$ & $6 / 4.0$ & $134 / 107.2$ & $131 / 104.8$ \\
\hline Ogasawarana arata Pilsbry & - & - & - & $2 / 1.6$ \\
\hline Paludinella minima Habe & - & - & $2 / 1.6$ & - \\
\hline Gastrocopta boninensis Pilsbry & - & $8 / 5.3$ & - & - \\
\hline Ptychalaea dedecora Pilsbry & - & - & $1 / 0.8$ & - \\
\hline Lamellidea biplicata Pilsbry \& Hirase & $12 / 12.0$ & - & $20 / 16.0$ & $4 / 3.2$ \\
\hline Tornatellides tryoni Pilsbry \& Cooke & - & $16 / 10.7$ & - & - \\
\hline Boninena callistoderma Pilsbry & $1 / 0.1$ & - & $1 / 0.1$ & $2 / 0.2$ \\
\hline Hirasea acutissima Pilsbry & $4 / 4.0$ & - & $69 / 55.2$ & $32 / 25.6$ \\
\hline Lamprocystis habajimana Pilsbry & $7 / 7.0$ & - & $60 / 48.0$ & $70 / 56.0$ \\
\hline Mandarina polita Chiba & $32 / 3.2$ & - & $112 / 11.2$ & $53 / 5.3$ \\
\hline Mandarina babajimana Pilsbry & $61 / 6.1$ & $5 / 0.5$ & $67 / 6.7$ & $100 / 10.0$ \\
\hline No. of 0.5 by $0.5 \mathrm{~m}$ quadrates per site & 4 & 6 & 5 & 5 \\
\hline No. of species & 7 & 4 & 9 & 8 \\
\hline
\end{tabular}

Note: Numbers of individuals found and population density $\left(\right.$ per $\left.\mathrm{m}^{2}\right)$ of each species at each site is shown. Numbers of individuals of Mandarina polita, Mandarina hahajimana, and Boninena callistoderma were obtained by searching a 10 by $10 \mathrm{~m}$ quadrat, and those of other species by searching 0.5 by $0.5 \mathrm{~m}$ quadrats placed at random within the 10 by $10 \mathrm{~m}$ quadrat. The number of 0.5 by $0.5 \mathrm{~m}$ quadrats placed within each 10 by $10 \mathrm{~m}$ quadrat is shown at the bottom of the table.

thick, large shell with a closed umbilicus. In addition, the Higashizaki populations have a variety of shell color patterns, some of which have not been found in any other populations of $M$. habajimana.

A

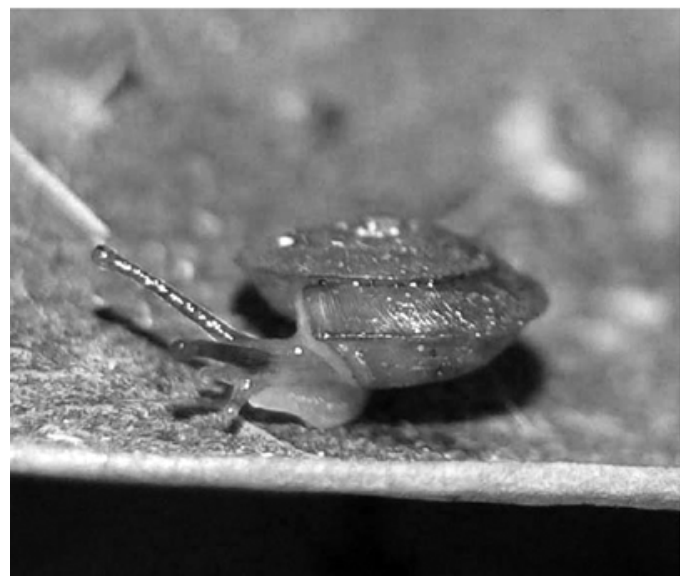

Ogasawarana yoshiwarana was the most common snail on Higashizaki, with a population density exceeding 100 individuals per square meter (Table 1). Densities of Hirasea acutissima and Lamprocystis hahajimana were
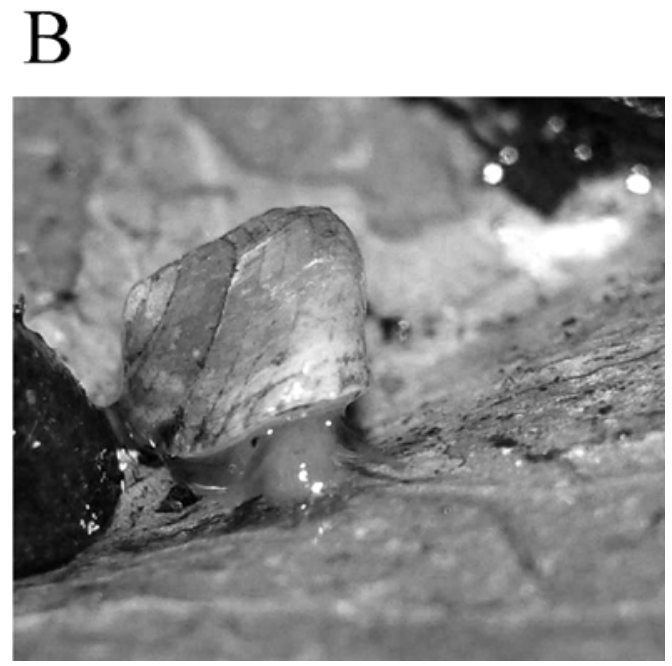

FIGURE 3. Photographs of species formerly believed to be extinct: (A) Hirasea acutissima, (B) Ogasawarana yoshiwarana. 
TABLE 2

Number of Native Land Snail Species (Indigenous Species Plus Species Endemic to Each Island) and Number of Land Snail Species Endemic to Each Island That Are Currently Found on Each Island of the Ogasawara Archipelago

\begin{tabular}{|c|c|c|c|c|}
\hline \multirow[b]{2}{*}{ Islands or Areas } & \multirow[b]{2}{*}{ Area $\left(\mathrm{km}^{2}\right)$} & \multicolumn{2}{|c|}{ No. of extant species } & \multirow{2}{*}{$\begin{array}{c}\text { Total No. of Native } \\
\text { Species Recorded } \\
\text { (Including Extinct Species) }\end{array}$} \\
\hline & & Native & Endemic to the Island & \\
\hline Chichijima & 24.0 & 11 & 1 & 42 \\
\hline Hahajima & 20.8 & 30 & 10 & 53 \\
\hline Anijima & 7.87 & 33 & 13 & 33 \\
\hline Ototojima & 5.20 & 10 & 0 & 12 \\
\hline Mukojima & 3.07 & 10 & 3 & 11 \\
\hline Anejima & 1.43 & 7 & 0 & 10 \\
\hline Mukoujima & 1.38 & 6 & 0 & 8 \\
\hline Meijima & 1.37 & 8 & 0 & 9 \\
\hline Imotojima & 1.22 & 9 & 0 & 9 \\
\hline Hirashima & 0.6 & 6 & 0 & 8 \\
\hline Higashizaki & 0.3 & 12 & 2 & 12 \\
\hline
\end{tabular}

Note: Numbers for Hahajima do not include species only found in Higashizaki (Ogasawarana yoshiwarana, Ogasawarana arata, Ptychalaea dedecora, Hirasea acutissima, and Lamprocystis habajimana).

also high and exceeded 50 individuals per square meter in one site. Ogasawarana yoshimarana, Mandarina polita, and M. bahajimana were found mainly in the palm litter, whereas H. acutissima and L. habajimana were in the broad-leaved litter. The population density of the large species, Mandarina polita and Mandarina hahajimana, was about 3-10 individuals per square meter. Few snails were found on trees, except for the arboreal species Boninena callistoderma on the trunks of palms. This species is extinct in all of the islands except Anijima and Higashizaki on Hahajima. Gastrocopta boninensis and Tornatellides tryoni were found in the bush around the forest.

The species richness of native land snails of the Higashizaki Peninsula was high despite its small area. For example, none of the other islands near Hahajima has as many extant native species as Higashizaki, even though their areas are much larger (Table 2). On the biggest island, Chichijima, the forested area of which is about 100 times larger than Higashizaki, only 11 native species are still found. Similarly, the forested area of Ototojima is more than 15 times larger than Higashizaki, but only 10 native snail species persist. Currently, 30 native species can be found in the main part of Hahajima, nearly half of which are also found on Higashizaki. In fact, only two islands or areas (Anijima and the main part of Hahajima) have a greater number of native species than Higashizaki (Table 2). In addition, in most of the other areas population densities are low; the population density of Hirasea acutissima on Higashizaki is particularly high.

\section{DISCUSSION}

The native land snail fauna of Hahajima is remarkably well preserved on Higashizaki. It is in effect a small "lost world" of Ogasawara. Unfortunately, invertebrates are often ignored as targets for conservation. Here it can be seen that even a small protected area can maintain a high proportion of an island's snail diversity. We found that the land snail fauna of Higashizaki is basically a subset of species that were previously recorded on $\mathrm{Ha}-$ hajima. However, because there is some isolation between the populations of the peninsula and those of the rest of the island, some differentiation may have occurred. Although no clear morphological differences were observed in most of the species, Mandarina babajimana is ecologically and morphologically distinct between the peninsula and the rest 
of the island, perhaps suggesting that it has been isolated in the peninsula for some time (Davison and Chiba 2006).

We think that it is unlikely that the snail fauna of the peninsula migrated from other islands near Hahajima recently (Anejima, Meijima, Imotojima, Mukoujima) because the species composition of the peninsula fauna is clearly different. The only species in common with those islands are Gastrocopta boninensis, Lamprocystis hahajimana, and Tornatellides tryoni, although Hirasea acuta, a species closely related to Hirasea acutissima and sometimes treated as a subspecies of the latter, is found in Hirashima and Imotojima. Hirasea acutissima from Higashizaki is distinguishable from Hirasea acuta by having a far larger and flatter shell with a sharp keel around the periphery. This therefore suggests that the Higashizaki fauna is not derived from elsewhere by recent immigration but is an original fauna that has been maintained in the peninsula to the present time. This is also supported by the fact that live individuals of half of the species of the Higashizaki fauna have not been found for more than 60 $\mathrm{yr}$ in the rest of Hahajima, and live specimens of Ogasawarana yoshiwarana has not been recorded in Ogasawara since its discovery over $100 \mathrm{yr}$ ago.

The forest of the Higashizaki Peninsula has been preserved because accessing this peninsula is very difficult. There is no record of cultivation on the peninsula since the initial colonization of the Ogasawara Islands by Japanese people in the 1880s, and the only visitors are occasional fisherman and scientists. In addition, alien predators such as flatworms may be unable to cross the eroded land bridge between the main part of the island and the peninsula. Thus, the land snail fauna of Higashizaki is most likely to be an original Ogasawaran endemic snail fauna that has been little influenced by human activity and introduced species.

Despite its small area, the high species richness of the Higashizaki fauna relative to other parts of Ogasawara suggests that original species diversity can be maintained in very small areas (less than $0.1 \mathrm{~km}^{2}$ ) if the vegetation is not degraded and alien predators have not been introduced. It is well known that a high species diversity of land snails can be found in an extremely small area (Solem et al. 1981, Solem and Climo 1985, Emberton 1995a, de Winter and Gittenberger 1998, Barker and Mayhill 1999, Schilthuizen and Rutjes 2001). The survival of many native land snail species may be possible in a small area because moist habitat can serve as a refuge even on a very small spatial scale ( $\mathrm{Hy}-$ lander et al. 2004) or because land snail faunas may not be highly structured by resource competition (Peake 1978, Cain 1983, Solem 1984, Emberton 1995b). Therefore, at the local level, variation in species richness with area may reflect ecological rather than biogeographic factors (Cameron et al. 2003).

In either case, our findings suggest that the small refugelike Higashizaki Peninsula could be important for the conservation of endemic land snails. Unfortunately, the small area could also prove its downfall if predatory flatworms were introduced or manage to cross the land bridge. Monitoring any habitat change and immigration of alien species is crucial to conserving this unique fauna, as is understanding the ecology and phylogenetic relationships of these species. We recommend that the access ridge should be monitored so that it remains without vegetation in parts, and that great care should be taken not to introduce predators when visiting.

\section{ACKNOWLEDGMENTS}

We express our sincere thanks to $\mathrm{H}$. Chiba and I. Okochi for assistance with this survey and to R. H. Cowie for helpful advice. This study was conducted under permits from the Agency for Cultural Affairs (No. 4-1555) and the South Kanto branch, Ministry of the Environment (No. 050815001).

\section{Literature Cited}

Barker, G., and P. C. Mayhill. 1999. Patterns of diversity and habitat relationships in terrestrial mollusc communities of the $\mathrm{Pu}-$ keamaru Ecological District, northeastern New Zealand. J. Biogeogr. 26:215-238. 
Cain, A. J. 1983. Ecology and ecogenetics of terrestrial molluscan populations. Pages 597-647 in W. D. Russel-Hunter, ed. The Mollusca, 6: Ecology. Academic Press, London.

Cameron, R. A. D., M. Mylonas, K. Triantis, A. Parmakelis, and K. Vardinoyannis. 2003. Land snail diversity in a square kilometer of Cretan maquis: Modest species richness, high density and local homogeneity. J. Molluscan Stud. 69:93-99.

Chiba, S. 1989. Taxonomy and morphologic diversity of Mandarina (Pulmonata) in the Bonin Islands. Trans. Proc. Palaeontol. Soc. Jpn. New Ser. 155:218-251.

Cowie, R. H. 2001. Decline and homogenization of Pacific faunas: The land snails of American Samoa. Biol. Conserv. 99:207222.

. 2002. Invertebrate invasions on $\mathrm{Pa}$ cific islands and the replacement of unique native faunas: A synthesis of the land and freshwater snails. Biol. Invas. 3:119-136.

Cowie, R. H., and A. C. Robinson. 2003. The decline of native Pacific island faunas: Changes in status of the land snails of Samoa through the 20th century. Biol. Conserv. 110:55-65.

Davison, A., and S. Chiba. 2006. Labile ecotypes accompany rapid cladogenesis in a land snail adaptive radiation. Biol. J. Linn. Soc. 88:269-282.

de Winter, A. J., and E. Gittenberger. 1998. The land-snail fauna of a square kilometer patch of rainforest in southwestern Cameroon: High species richness, low abundance and seasonal fluctuations. Malacologia 40:231-250.

Emberton, K. C. 1995a. Land-snail community morphologies of the highest-diversity sites of Madagascar, North America, and New Zealand, with recommended alternatives to height-diameter plots. Malacologia 36:43-66.

- 1995b. Sympatric convergence and environmental correlation between two land-snail species. Evolution 49:469-475.

Habe, T. 1969. Mollusks in Ogasawara. Iden 23:19-25.

Hylander, K., C. Nilsson, and T. Gothner. 2004. Effects of buffer-strip retention and clearcutting on land snails in boreal riparian forests. Conserv. Biol. 18:1052-1062.

IUCN (International Union for Conservation of Nature and Natural Resources). 2004. 2004 IUCN Red List of Threatened Species. Available online at http://www .redlist.org/.

Kuroda, T. 1930. Land and freshwater mollusks in Ogasawara Islands. Jpn. J. Biogeogr. 13:195-204.

Kurozumi, T. 1988. Species composition and abundance of land mollusks and factors affecting their extinction in the Ogasawara Islands. Ogasawara Res. 15:59-109.

Lydeard, C., R. H. Cowie, W. F. Ponder, A. E. Bogan, P. Bouchet, S. A. Clark, K. S. Cummings, T. J. Frest, O. Gargominy, D. G. Herbert, R. Hershler, K. Perez, B. Roth, M. Seddon, E. E. Strong, and F. G. Thompson. 2004. The global decline of nonmarine mollusks. BioScience 54:321330.

Minato, H. 1979. Distribution and ecology of land snails in Ogasawara. Anim. Nat. 98:21-24.

Ministry of Environment Japan. 2000. The threatened wildlife of Japan (Red List of Threatened Species of Japan). Available online at http://www.biodic.go.jp/english/ $\mathrm{rdb} / \mathrm{rdb}$ _f.html.

Murray, J., E. Murray, M. S. Johnson, and B. Clarke. 1988. The extinction of Partula on Moorea. Pac. Sci. 42:150-153.

Okochi, I., H. Sato, and T. Ohbayashi. 2004. The cause of mollusk decline on the Ogasawara Islands. Biodiv. Conserv. 13:14651475.

Peake, J. 1978. Distribution and ecology of the Stylommatophora. Pages 429-526 in V. Fretter and J. Peake, eds. Pulmonates, 2A: Systematics, evolution and ecology. Academic Press, London.

Pilsbry, H. A. 1902. New land Mollusca from Japan and the Bonin Islands. Proc. Acad. Nat. Sci. Phila. 54:25-32.

Schilthuizen, M., and H. A. Rutjes. 2001. Land-snail diversity in a square kilometre of tropical rainforest in Sabah, Malaysian Borneo. J. Molluscan Stud. 67:417-423.

Shimizu, Y., K. Tomiyama, T. Yasui, M. Funakoshi, M. Ito, N. Kawakubo, and S. 
Honma. 1991. Evaluation of human impact on the nature of Chichijima Retto in the Ogasawara (Bonin) Islands. Reg. Views 4:67-86.

Solem, A. 1984. A world model of land-snail diversity and abundance. Pages 6-22 in A. Solem and A. C. van Bruggen, eds. Worldwide snails. E. J. Brill/W. Backhuys, Leiden.

Solem, A., and F. M. Climo. 1985. Structure and habitat correlations of sympatric New Zealand land snail species. Malacologia 26:1-30.
Solem, A., F. M. Climo, and D. J. Rosco. 1981. Sympatric species diversity of New Zealand land snails. N. Z. J. Zool. 8:453485.

Tomiyama, K., and T. Kurozumi. 1991. Living condition and conservation of land snails in the Ogasawara Islands. Pages 245-281 in M. Ono, M. Kimura, K. Miyasita, and M. Nogami, eds. Report of the second general survey of natural environment of the Ogasawara Islands. Bureau of Environment, Tokyo Metropolitan Office, Tokyo, Japan. 
